\title{
O PERFIL E O ESTUDO DO COMPORTAMENTO HUMANO NOS ACIDENTES DE TRÂNSITO: O USO DO CELULAR EM CURITIBA
}

\author{
M. A. P. Bernardinis ${ }^{1}$, L. L. V. Ruiz ${ }^{2 ;}$ J. T. Bastos ${ }^{3}$ \\ ${ }^{1,3}$ Professor da UFPR. Centro Politécnico, Dep. de Transportes, bloco V, Jd. das Américas \\ ${ }^{2}$ Graduando da UFPR, Curso de Engenharia Civil. Centro Politécnico, Jd. das Américas \\ profmarcia.map@gmail.com ${ }^{1}$,lucas_lvr@yahoo.com.br ${ }^{2}$, jtbastos@gmail.com ${ }^{3}$
}

\begin{abstract}
Resumo: Uma das maiores preocupaçôes da comunidade científica e dos órgãos responsáveis pelo planejamento do trânsito e da segurança das cidades é encontrar soluçóes que possam minimizar o número de vítimas, fatais ou feridas, por acidentes de trânsito. Analisar os acidentes e compreender melhor esses fatos, pode ajudar a reduzir ou até prevenir a sua ocorrência e seu impacto na sociedade. Entretanto, raros são os estudos encontrados nessa área quando o foco é o uso do celular. Assim, esse trabalho realizou uma pesquisa na cidade de Curitiba a fim de traçar um perfil e estudo do comportamento humano com relação ao uso do celular enquanto dirige. O estudo revelou, entre outras coisas, que apesar dos condutores saberem dos riscos que o telefone celular causa direta e indiretamente quando estão ao volante, eles continuam a utilizá-lo mesmo depois de sofrer algum acidente ou multa.
\end{abstract}

Palavras-chave: Acidentes de trânsito, Comportamento humano, Celular.

\section{Introduçáo}

De acordo com [1] os acidentes de trânsito constituem um problema para a saúde pública em virtude do grande impacto na morbidade e mortalidade. Estimativas da OMS por ano, são registrados no mundo cerca de 1,2 milháo de mortes no trânsito, o que vem representar um total de três mil mortes por dia. De acordo com [2], a maioria das pesquisas aponta o fator humano como o responsável direto ou indireto por $65 \%$ a $95 \%$ dos acidentes de trânsito. Para [3], entre os principais riscos associados ao fator humano se encontram a falta de atenção e a distração dos motoristas. Assim, sabe-se que com relação a falta de atenção do motorista, associa-se entre outros o uso do celular. Segundo [5], o uso do celular no trânsito é uma das causas mais recorrentes, além de ser um grande causador de acidentes, ficando atrás apenas do excesso de velocidade e consumo de álcool e drogas.

\section{Metodologia}

Para avaliar o comportamento e o perfil dos condutores foi elaborado um questionário aplicado na cidade de Curitiba - PR, tanto como disponibilizado um questionário online em Googles Forms nas redes sociais como Facebook e Whatsapp para obter maior abrangência de respostas e uma heterogeneidade nas respostas. Assim, foram feitas 240 entrevistas nas vias de Curitiba com os motoristas e 370 pelas redes sociais. Os dados foram coletados de agosto a outubro de 2016. 


\section{Resultados esperados/Conclusóes}

Com este estudo, percebeu-se alguns fatos que merecem destaque. Por exemplo, em ambos os sexos, numa faixa etária de 18 a 44, utilizam ainda o telefone celular enquanto fazem seus deslocamentos diários, acreditando que nada irá acontecer, mesmo já tendo sido multado ou sofrido algum tipo de acidente. Esta ausência de percepçáo do risco leva muitos a permanecerem usando o celular enquanto conduzem, fazendo-se necessário urgente açôes que possam mitificar os comportamentos de uso do celular na condução de veículos.

\section{Referências}

[1] ORGANIZAÇÃO MUNDIAL DA SAÚDE-OMS, 2014. Disponível em: <iris.onsv.org.br/portaldados/ downloads/retrato2014.pdf>. Acesso em: 8 abr. 2016.

[2] MACEDO, G. M. Estudos das relaçôes entre o nível de habilidade e direção segura, a irritabilidade e o cometimento de violaçóes e erros do motorista e o seu possível envolvimento em acidentes de trânsito. Tese de D.Sc , 2004. USP, SP.

[3] GAO - General Accounting Office. Research continues on the variety of factors that contribute to motor vehicle crashes. Report to congressional requesters, 2003. Disponível em: < http://www.gao.gov/new.items/d03436. pdf>. Acesso em: 14 maio 2016.

[4] VIEIRA, M. Uso do Celular ao dirigir é causa mais comum de desatenção no trânsito. Disponível em: <http:// wwwl.folha.uol.com.br> Acesso em: 30 out. 2017. 